\title{
VIRULENCE OF ALTERNARIA ALTERNATA INFECTING NONI ASSOCIATED WITH PRODUCTION OF CELL WALL DEGRADING ENZYMES
}

\author{
Manjunath Hubballi*, Archana Sornakili, Sevugapperumal Nakkeeran \\ Theerthagiri Anand, Thiruvengadam Raguchander
}

Department of Plant Pathology, Centre for Plant Protection Studies

Tamil Nadu Agricultural University, Coimbatore - 641003, India

Received: August 18, 2010

Accepted: December 21, 2010

\begin{abstract}
Different methods of inoculations were tried for proving Koch postulates. Among them, the pin prick plus spore suspension spray was found be the best method used in a glasshouse. Out of the fifteen isolates of Alternaria alternata, isolate AA1 was highly virulent and AA6 was avirulent. The virulent isolate of A. alternata produced more cellulolytic (C1 and Cx) and pectinolytic (macerating enzymes, pectin methyl esterase and endo-polygalacturonase) enzymes in vitro than the avirulent one. The activity of cellulolytic enzymes increased with the increase in the age of the culture. Whereas, the pectinolytic enzymes were highly active in 10-day-old culture and the activities decreased with the increase in the age of the culture. Then again, the activity of enzymes produced by the avirulent isolate of pathogens did not decrease and these enzyme activities increased with the increase in the age of the culture.
\end{abstract}

Key words: Noni, leaf blight, virulent, avirulent, cellulolytic and pectinolytic enzymes and mycelial dry weight

\section{INTRODUCTION}

Morinda citrifolia, popularly known as noni, has been generating great enthusiasm within the green health industry for the past two decades. Noni has been promoted as a treatment for a vast array of medical conditions ranging from cancer to sexual dysfunction. In India it is distributed in Tamil Nadu, Karnataka, Andhra Pradesh, Orissa, Madhya Pradesh, Gujarat, Rajasthan and Andaman Nicobar islands; which means; over 1850 acres (Peter 2009). The intensive cultivation of noni has resulted in the outbreak of several foliar diseases caused by fungi, and can reduce leaf growth and fruit development (Nelson 2006). Leaf blight caused by Alternaria alternata, is one from among all the important diseases that threaten noni production.

Virulence is the measure or degree of pathogenecity of an isolate or race in the host (Singh 2002). It is well established that virulence of different pathogens, of the same host, vary. Even the isolates of same pathogen exhibit differences. Virulence of a particular pathogen is mainly governed by the capacity to produce toxins, enzymes and other physiological factors. Although for many plant pathogens, a capacity to breach the cell walls of their hosts is not required for entry. This is because these pathogens rely on wounds, natural openings or vectors. Many fungal pathogens achieve entry by mechanical force or enzyme activity or a combination of both. A considerable amount of literature has accumu- lated that implicates degradative enzymes in pathogenesis or virulence. Cell wall degrading enzymes released by pathogens are known to be responsible for pathogenesis. The ability of a pathogen to produce cellulolytic and pectinolytic enzymes determines the degree of cell wall degradation during pathogenesis and inhibition of these enzymes, and ultimately affects the disease development. A numbers of cell wall degrading enzymes have been shown to be produced by plant pathogens (Chenglin et al. 1996) which are known to facilitate cell wall penetration and tissue maceration in host plants. These microorganisms produce metabolites in culture media and plant tissues which were involved in the disease syndrome (Wood et al. 1972). Several species of Alternaria were known to produce different types of metabolites (Bhaskaran and Kandaswamy 1978). The aims of the present study were to select the best method of plant inoculation and to understand the pathogenicity mechanism, and also to assess virulence of the isolates and its relevance to the production of cell wall degrading enzymes and pathogenisis.

\section{MATERIALS AND METHODS}

\section{Collection, isolation and establishment of isolates}

The infected noni leaves showing typical symptom of leaf blight were collected from Tamil Nadu, Karnataka and Kerala. The pathogens were isolated by the tissue segment method (Rangaswami 1958). The fungus was 
purified by the single spore isolation technique (Ricker and Ricker 1936) and the purified isolates were maintained on PDA slants for further studies.

\section{Methods of Inoculation}

Five different methods of inoculation were tried for pathogenicity testing, to select the best method which may be standardized for proving pathogenicity and to study pathogen virulence. The isolate AA1 of A. alternata was used for this study. While in a glasshouse, two month old seedlings were inoculated through different methods (mycelial inoculation, pin prick plus mycelial inoculation, spore suspension spray, pin prick plus spore suspension spray, and spore injection). The seedlings were exposed to 80 per cent $\mathrm{RH}$, both $24 \mathrm{~h}$ prior and after inoculation, by covering the seedlings with a polythene bag and spraying water inside the bag. The inoculation was done during the cool evening hours. Three replications were maintained in each method. Fifteen days after inoculation, the disease intensity was recorded in all methods.

\section{Assessment of PDI}

Plants showing the symptoms of leaf blight were assessed as per the severity grade from $0-9$ and the per cent disease index, were calculated. The disease intensity of leaf blight was assessed as proposed by TNAU (1980), according to a grade chart: 0 - No. infection, $1-0$ to 10.00 , $3-10.1$ to $15.00,5-15.1$ to $25.00,7-25.1$ to $50.00,9-$ more than 50.00 per cent of leaf area infected.

The per cent disease index (PDI) was calculated using Mc Kinney's (1923) formula:

$\mathrm{PDI}=\frac{\text { Sum of all numerical grades }}{\text { Total number of leaves counted }} \times \frac{100}{\text { Maximum category value }}$

\section{Virulence of isolates}

Various isolates of A. alternata were inoculated onto two month old seedlings of noni maintained in a glasshouse, using the pin prick plus spore suspension spray method (Lakshmanan et al. 1990). Three replications were maintained for each isolate with five seedlings for each replication. The symptoms were observed 15 days after inoculation. Ten leaves per plant were randomly selected for each isolate and the PDI was calculated according to Mc Kinney's formula (1923).

\section{Production of cell wall degrading enzymes}

To study the in vitro production of pectinolytic and cellulolytic enzymes, the isolates; namely AA1 and AA6, were grown on Czapek dox broth $(\mathrm{pH} 7-7.5)$ wherein the carbon source was substituted with one per cent pectin (for pectic enzymes) or one per cent carboxy methyl cellulose (for cellulolytic enzymes). The media were inoculated with a $9 \mathrm{~mm}$ diameter of a nine day old actively growing culture disc, of each isolate. The culture filtrates were obtained after incubation at room temperature $\left(27 \pm 1^{\circ} \mathrm{C}\right)$ for $5,10,15$ and 20 days and centrifuged at $3000 \mathrm{~g}$, for $20 \mathrm{~min}$. For the assay of pectinolytic enzymes, the culture filtrates were dialyzed for $18 \mathrm{~h}$ against distilled water at $40^{\circ} \mathrm{C}$. The dialysate served as enzyme source. As dialysis was found to reduce the activity of cellulolytic enzymes (Bateman 1964), the culture filtrates as such were used for the assay of cellulases.

\section{Assay of cellulolytic enzymes}

\section{Cellulase $\left(C_{1}\right)$ activity}

Cellulase $\left(C_{1}\right)$ activity was assayed by the method of Norkrans (1950). The assay mixture contained $1 \mathrm{ml}$ of cellulose solution (the concentration of which was adjusted to give approximately 0.85 absorbance at $610 \mathrm{~nm}$ ), four $\mathrm{ml}$ of $0.1 \mathrm{M}$ phosphate buffer ( $\mathrm{pH} 7.0$ ), and $5 \mathrm{ml}$ of enzyme source. The absorbance of the assay mixture was determined at $610 \mathrm{~nm}$ in a Spectronic - 20 immediately upon the addition of the enzyme source, and again after an incubation period of $24 \mathrm{~h}$ at $27^{\circ} \mathrm{C}$. The enzyme activity was expressed in units ( 1 unit $=$ change in absorbance of 0.01 ).

\section{Cellulase $\left(C_{x}\right)$ activity}

Cellulase $\left(C_{x}\right)$ activity was assayed by the viscosimetric method of Hancock et al. (1964) using Carboxy methyl cellulose (CMC) as the substrate. Two $\mathrm{ml}$ of enzyme extract was added to four $\mathrm{ml}$ of 1.2 per cent carboxy methyl cellulose solution buffered at $\mathrm{pH} 5.0$ with sodium citrate buffer. The loss of viscosity of the CMC solution was determined by means of an Ostwald-Fenske viscosimeter size 150 at five min. intervals, for up to $15 \mathrm{~min}$. The enzyme source which boiled for $10 \mathrm{~min}$. at $100^{\circ} \mathrm{C}$, served as the check. The results were expressed as the per cent loss in viscosity in $15 \mathrm{~min}$.

$$
\mathrm{V}=\frac{\mathrm{T}_{0}-\mathrm{T}_{1}}{\mathrm{~T}_{0}-\mathrm{T}_{\mathrm{w}}} \times 100
$$

where:

$\mathrm{V}$ - per cent loss of viscosity,

$\mathrm{T}_{0}$ - flow time in seconds at zero time,

$\mathrm{T}_{1}$ - flow time of the reaction mixture at time $\mathrm{T}_{1^{\prime}}$

$\mathrm{T}_{\mathrm{w}}$ - flow time of distilled water.

\section{Assay of pectinolytic enzymes}

\section{Macerating enzymes}

Macerating enzyme activity was assessed by the method described by Mahadevan (1965). Potato discs of nine mm diameter and $30 \mu \mathrm{m}$ thickness were obtained by using a hand microtome. Ten potato discs were placed in a sterile Petri plate and $10 \mathrm{ml}$ of the culture filtrate were added. The uninoculated medium served as the control. The coherence of the potato discs was tested at different time intervals using a sterile glass rod. The enzyme activity was expressed as the time taken in hours for maceration of potato discs.

\section{Pectin methyl esterase (PME)}

Pectin methyl esterase activity was estimated following the procedure described by Gupta (1970). Pipetted out $20 \mathrm{ml}$ of pectin solution and its $\mathrm{pH}$ were adjusted to 7.0 using one $\mathrm{N}$ sodium hydroxide. To this, $10 \mathrm{ml}$ of enzyme solution was added and its $\mathrm{pH}$ was adjusted immediately 
to 7.0 in the $\mathrm{pH}$ meter by adding one $\mathrm{N}$ sodium hydroxide. The enzyme substrate mixture was incubated for $24 \mathrm{~h}$. The $\mathrm{pH}$ was readjusted to seven with $0.02 \mathrm{~N}$ sodium hydroxide, which was equal to the enzyme activity and the enzymatic activity, and was expressed in terms of units (one unit is $0.1 \mathrm{ml}$ of $0.02 \mathrm{~N}$ sodium hydroxide used).

\section{Endo-polygalacturonase (endo PG)}

Endo-PG activity was estimated by the standard viscosimetric method (Hancock et al. 1964) using three $\mathrm{ml}$ of enzyme source, one $\mathrm{ml}$ of 1.2 per cent sodium polypectate and one $\mathrm{ml}$ of $0.5 \mathrm{M}$ ammonium acetate buffer. The loss in viscosity of the pectate solution was determined by means of the Ostwald-Fenske vicosimeter size 150, at five min intervals for up to $15 \mathrm{~min}$. The enzyme source which boiled for $10 \mathrm{~min}$. at $100^{\circ} \mathrm{C}$ served as the check. The results were expressed as the per cent loss in viscosity in $15 \mathrm{~min}$.

\section{Statistical analysis}

All the experiments were repeated once with similar results. The data were statistically analyzed (Gomez and Gomez 1984). The treatment means were compared by Duncan's multiple range test (DMRT). The package used for analysis was IRRISTAT version 92-a developed by International Rice Research Institute Biometrics Units, The Philippines.

\section{RESULTS}

\section{Collection and isolation of pathogens}

Leaves showing typical symptoms of leaf blight were collected from fifteen noni growing areas of Tamil Nadu, Karnataka and Kerala. From these leaf samples, a total of fifteen isolates were isolated and purified.

\section{Methods of inoculation}

The results indicated that the intensity of disease symptoms varied significantly with that of different methods of inoculation. Among which, the pin prick with spore suspension spray method was the best, which recorded 58.60 PDI, followed by the pin prick with mycelial inoculation method (52.23 PDI). The lowest PDI was recorded in the mycelial inoculation method (16.37 PDI) (Fig. 1). Hence, for further studies, the pin prick plus spore suspension spray was used.

\section{Virulence of the isolates}

The data from the virulence study clearly indicated that different isolates varied with respect to virulence. The maximum PDI was recorded in AA1 (61.00 PDI) followed by AA10 (60.33 PDI), AA11 (56.34 PDI) and AA2 (54.07 PDI). The minimum disease intensity was recorded in AA6 which showed 10.33 PDI. The results clearly indicated that isolate AA1 was highly virulent and isolate AA6 was least virulent. Hence, these two isolates were used for production of cell wall degrading enzymes (Fig. 2).

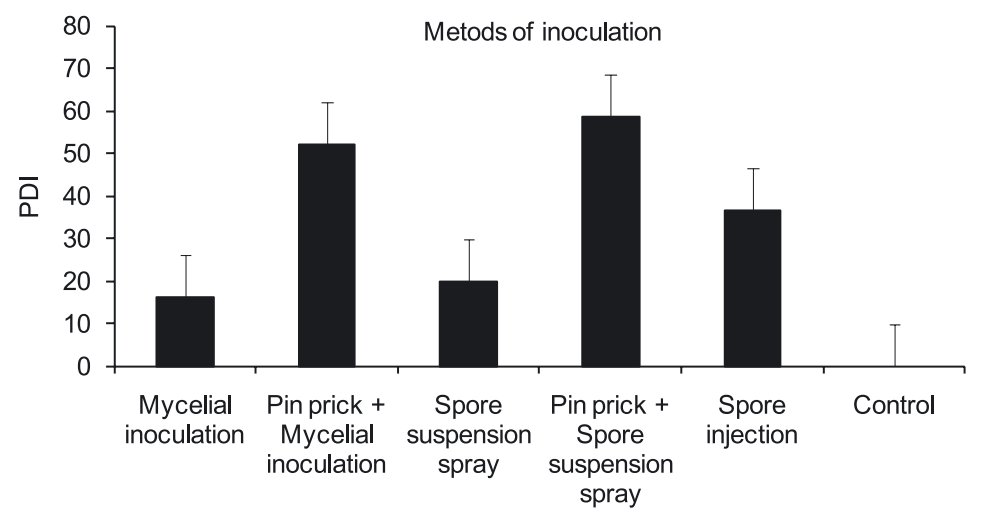

PDI - per cent disease index

Fig. 1. Effect of different inoculation methods on severity of leaf blight disease under glasshouse conditions

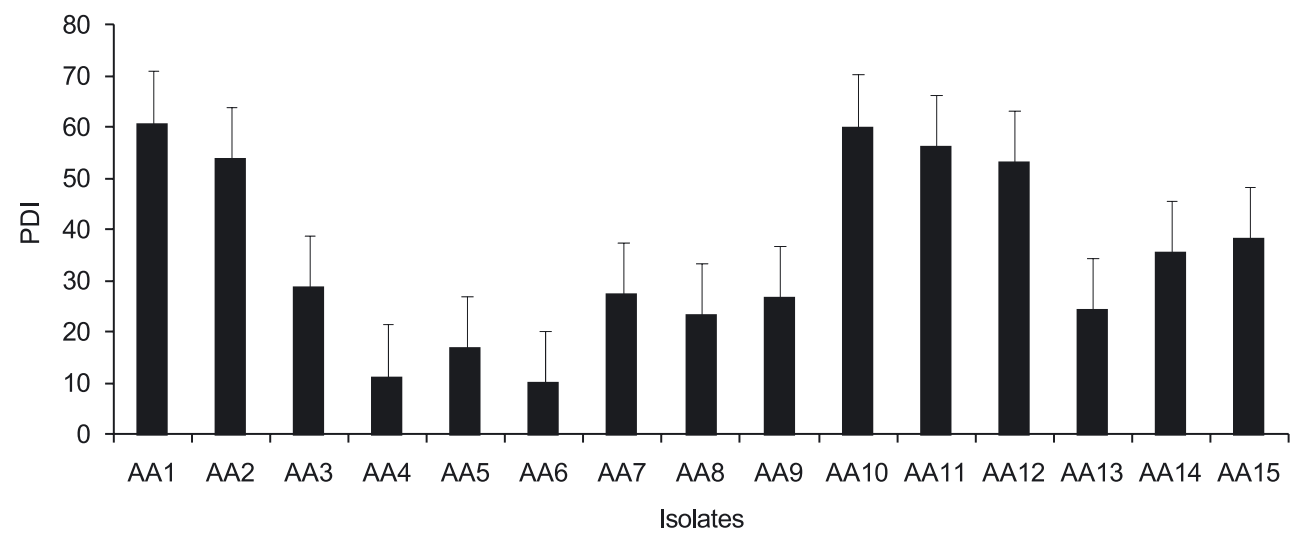

Fig. 2. Virulence of A. alternata isolates on noni seedlings under glasshouse conditions 


\section{Production of cell wall degrading enzymes}

\section{In vitro production of cellulolytic enzymes}

The enzyme production increased with an increase in the incubation period. The virulent isolate of A. alternata produced more cellulolytic enzymes $\left(C_{1}\right.$ and $\left.C_{x}\right)$ than the avirulent ones. The $\mathrm{C}_{1}$ activity was found to be more (12.00 units) in 20-day-old culture filtrate of virulent isolate of A. alternata than the avirulent ones (0.90 units). Similarly, the $C_{x}$ enzyme activity was found to be more (76.00 per cent loss of viscosity), in 20 day old culture filtrate of virulent isolate than the avirulent ones (0.90 units). Mycelial dry weight also increased with an increase in the incubation period. The dry weight of mycelium was higher in the virulent isolate $(480 \mathrm{mg})$ as compared to the avirulent ones (95 mg) (Table 1).

\section{In vitro production of pectinolytic enzymes}

In the virulent isolate, the production of the pectinolytic enzymes viz., macerating enzymes, Pectin methyl esterase (PME) and Endo polygalacturonase (Endo-PG) increased for up to 10 days and thereafter the activities of the enzymes decreased. Maximum enzyme activity was observed in the culture filtrate 10 days after incubation. In the avirulent isolate, the enzyme production increased with an increase in the incubation period (throughout the experimental period) but it was much less than the virulent isolates. The mycelial weight increased with an increase in the incubation period in both virulent and avirulent isolates of $A$. alternata (Table 2).

Table 1. Production of cellulolytic enzymes by A. alternata

\begin{tabular}{|c|c|c|c|c|}
\hline \multirow{2}{*}{ Isolate } & Incubation time [days] & $\mathrm{C}_{1}{ }^{1}$ & $\mathrm{C}_{\mathrm{x}}{ }^{2}$ & $\begin{array}{c}\text { Mycelial dry weight } \\
{[\mathrm{mg}]^{3}}\end{array}$ \\
\hline \multirow{3}{*}{ Virulent (AA1) } & 5 & $6.50 \mathrm{~d}$ & $42.50 \mathrm{~d}(40.68)$ & $240.00 \mathrm{~d}$ \\
\cline { 2 - 5 } & 10 & $7.30 \mathrm{c}$ & $51.80 \mathrm{c}(46.03)$ & $375.00 \mathrm{c}$ \\
\cline { 2 - 5 } & 15 & $10.50 \mathrm{~b}$ & $71.00 \mathrm{~b}(57.41)$ & $475.00 \mathrm{~b}$ \\
\cline { 2 - 5 } & 20 & $12.00 \mathrm{a}$ & $76.00 \mathrm{a}(60.66)$ & $480.00 \mathrm{a}$ \\
\cline { 2 - 5 } Avirulent (AA6) & 5 & $0.20 \mathrm{c}$ & $00.50 \mathrm{c}(4.05)$ & $70.00 \mathrm{~d}$ \\
\cline { 2 - 5 } & 10 & $0.20 \mathrm{c}$ & $00.70 \mathrm{~b}(4.79)$ & $85.00 \mathrm{c}$ \\
\cline { 2 - 5 } & 15 & $0.70 \mathrm{~b}$ & $00.90 \mathrm{a} \mathrm{(5.44)}$ & $95.00 \mathrm{~b}$ \\
\hline
\end{tabular}

${ }^{1}$ enzyme activity in units; ${ }^{2}$ per cent loss of viscosity; ${ }^{3}$ mean of three replications

Values in parentheses are arcsine transformed values

Table 2. Production of pectinolytic enzymes by A. alternata

\begin{tabular}{|c|c|c|c|c|c|}
\hline Isolate & $\begin{array}{c}\text { Incubation time } \\
\text { [days] }\end{array}$ & $\begin{array}{l}\text { Macerating } \\
\text { enzymes }^{1}\end{array}$ & $\begin{array}{c}\text { Pectin methyl } \\
\text { esterase }^{2}\end{array}$ & $\begin{array}{c}\text { Endopoly- } \\
\text { galacturonase }^{3}\end{array}$ & $\begin{array}{c}\text { Mycelial dry } \\
\text { weight }[\mathrm{g}]^{4}\end{array}$ \\
\hline \multirow{4}{*}{ Virulent (AA1) } & 5 & $15.00 \mathrm{c}$ & $04.50 \mathrm{c}$ & 23.50 c (28.99) & $250.00 \mathrm{~d}$ \\
\hline & 10 & $15.00 \mathrm{c}$ & $10.75 a$ & 59.70 a ( 50.59) & $385.00 \mathrm{c}$ \\
\hline & 15 & $18.00 \mathrm{~b}$ & $08.75 b$ & $40.00 \mathrm{~b}(39.23)$ & $590.00 \mathrm{~b}$ \\
\hline & 20 & $24.00 \mathrm{a}$ & $08.00 \mathrm{~b}$ & 24.00 c (29.33) & $695.00 a$ \\
\hline \multirow{4}{*}{ Avirulent (AA6) } & 5 & no maceration & $01.00 \mathrm{c}$ & $04.30 \mathrm{~d}(11.96)$ & $060.00 \mathrm{~d}$ \\
\hline & 10 & no maceration & $02.75 b$ & $10.10 \mathrm{c}(18.53)$ & $075.00 \mathrm{c}$ \\
\hline & 15 & no maceration & $05.75 a$ & $20.36 b(26.82)$ & $089.00 \mathrm{~b}$ \\
\hline & 20 & no maceration & $05.75 a$ & $22.24 \mathrm{a}(28.13)$ & $110.00 \mathrm{a}$ \\
\hline
\end{tabular}

${ }^{1}$ time taken for maceration $(\mathrm{h}){ }^{2}$ enzyme activity in units; ${ }^{3}$ per cent loss of viscosity

${ }^{4}$ mean of three replications; values in parentheses are the arcsine transformed value

\section{DISCUSSION}

In the present study different methods of inoculation of pathogen for proving Koch postulates were tried. Results indicated that pin prick plus spore suspension spray method of inoculation significantly recorded the maximum leaf blight symptom. The maximum infection caused in the pin prick plus spore suspension spray method might be attributed to the ideal conditions like injury, ready to entry of the pathogen into the plant, ready access to the food available to the pathogen, and possibly the absence of competition and antagonism by microorganisms (inside the plant). Similar inoculation methods were reported by Anand (2002) in chili fruits against A. alternata.
Plant pathogens usually express several virulence functions that increase their ability to colonize and damage host plants. Variation in the virulence of $A$. brassicae (Awasthi and Kolte 1989), A. alternata (Anand 2002) and $A$. tenuis (Muthulakshmi 1990) was reported earlier. In our study among fifteen isolates of A. alternata, the maximum disease intensity was recorded with the isolate AA1 followed by AA11, and the least disease incidence with AA6. Variation in the virulence may be attributed to the genetic make up of the isolate. In addition the cultivar susceptibility, environmental factor, and the toxins and enzyme production capacity of pathogenic isolates, determines the virulence. 
Fungal pathogens are able to produce a variety of enzymes degrading the plant cell wall, and these enzymes help the pathogens in penetration and colonization of their host plants (Yang et al. 2005). In the present investigation, the pathogen $A$. alternata produced both cellulolytic enzymes $\left(\mathrm{C}_{1}\right.$ and $\mathrm{C}_{\mathrm{x}}$ ) and pectinolytic enzymes (macerating enzymes, PME and endo PG) in vitro.

Cellulose is a major structural constituent of the cell wall of host plants. Many phytopathogenic fungi produce cellulases in culture adaptively which hydrolyse cellulose and its derivatives (Marimuthu et al. 1974; Muthulakshmi 1990). The results obtained in the present study, indicated that the pathogens $A$. alternata produced $C_{1}$ and $C_{x}$ in vitro and the activity of these enzymes increased with the increase in the age of the culture. The virulent isolates of A. alternata produced more cellulolytic $\left(C_{1}\right.$ and $\left.C_{x}\right)$ enzymes than the avirulent ones. Similarly, Anand et al. (2008) reported high cellulase activity in the culture filtrate of virulent $A$. alternata and C. capsici. Anand et al. (2008) also reported that A. alternata and C. capsici produced extra cellular enzymes which degraded CMC and cellulose. Many phytopathogenic fungi produce cellulases in culture adaptively which hydrolyse cellulose and its derivatives (Marimuthu et al. 1974; Muthulakshmi 1990).

In the present investigation, the virulent isolates of A. alternata produced more macerating enzymes, PME and Endo-PG in vitro, than the avirulent ones. All the pectinolytic enzymes were highly active in the culture filtrate up to 10 days of age and thereafter, the activity slowly decreased. The maceration of potato discs increased with the increase in age of the culture in vitro, up to 10 days. Maximum pectinolytic enzymes in the culture filtrate occurred up to 10 days, indicating the role of these enzymes in pathogenicity. This corroborated with the observation of Muthulakshmi (1990) and Anand et al. (2008) in the case of A. alternata, causing fruit rot of chili. The enzyme PG hydrolytically cleaves pectin in such a manner that the $\beta-1,4$-glycosidic bonds of the chain are split (Bateman and Miller 1966). PME removes the esterified methyl group from the pectin chain hydrolytically (Goodman et al. 1967).

All these cell wall splitting enzymes are mostly adaptive, secreted by the pathogen in the presence of appropriate substrates. Pectinolytic enzymes were produced only in the presence of pectin in the medium. Cellulolytic enzymes were produced only in cellulose containing medium. Jha and Gupta (1988) reported, that the combination of glucose and pectin (or) polypectate induced secretion of endo-PG and endo-PMG in A. triticina infecting wheat.

The production and activity of pectinolytic and cellulolytic enzymes detected in vitro suggest their active role in disease development by the pathogen in noni leaves. Since the fungi A. alternata is intercellular in the host, the production of these enzymes appears to facilitate the dissolution of host cell wall and middle lamella and help the entry and establishment of the pathogen in the host, and is possibly responsible for playing a vital role in pathogenesis through cell wall degradation and disintegration of tissues.

\section{ACKNOWLEDGEMENTS}

The authors would like to thank the World Noni Research Foundation, Chennai, India for the financial support which enabled carrying out this research.

\section{REFERENCES}

Anand T. 2002. Studies on fruit rot of chilli (Capsicum annuum L.) caused by Colletotrichum capsici (Syd.) Butler and Bisby and Alternaria alternata (Fr) Keissler. M.Sc. (Ag.) thesis, Tamil Nadu Agric. Univ. Coimbatore, India, 157 pp.

Anand T., Bhaskaran R., Raguchander T., Karthikeyan G., Rajesh M., Senthilraja G. 2008. Production of cell wall degrading enzymes and toxins by Colletotrichum capsici and Alternaria alternata causing fruit rot of chillies. J. Plant Protection Res. 48 (4): 437-451.

Awasthi R.P., Kolte S.J. 1989. Variability in Alternaria brassicae affecting rape seed and mustard. Indian Phytopathol. 42, p. 863.

Bateman D.F. 1964. Cellulase and the Rhizoctonia disease of bean. Phytopathology 54 (11): 1372-1377.

Bateman D.F., Miller R. 1966. Pectic enzymes in tissue degradation. Annu. Rev. Phytopathol. 4: 119-146.

Bhaskaran R., Kandaswamy T.K. 1978. Production of a toxic metabolite by Alternaria helianthi in vitro and in vivo. Madras Agric. J. 65: 801-804.

Chenglin Y.,William S.C., Carl E.S. 1996. Purification and characterization of polygalacturanase produced by Penicillium expansum in apple fruit. Phytopatholgy 86 (11): 1160-1166.

Gomez K.A., Gomez A.A. 1984. Statistical Procedure for Agricultural Research. Wiley, New York, 680 pp.

Goodman R.N., Kiraly Z., Zaitlin M. 1967. The Biochemistry and Physiology of Infectious Plant Disease. Co., Inc. Princeton, New Jersey, 354 pp.

Gupta T. 1970. In vitro and in vivo production of pectolytic and cellulolytic enzymes by four isolates of Colletotrichum. p. 197-207. In: "Physiology of Parasitism" (G.P. Agarwal, K.S. Bilgrami, eds.). Today and Tomorrow's, New Delhi, 284 pp.

Hancock J.G., Miller R.L., Lorbeer J.W. 1964. Pectinolytic and cellulolytic enzymes produced by Botrytis alli, Botrytis cinerea and Botrytis squamosa in vitro and in vivo. Phytopathology 54 (8): 928-931.

Jha D.K., Gupta D.P. 1988. Production of pectinolytic enzymes by Alternaria triticina. Indian Phytopathol. 41, p. 652.

Lakshmanan P., Jeyarajan R., Vidhyasekaran P. 1990. A boll rot of cotton caused by Corynespora cassiicola in Tamil Nadu, India. Phytoparasitica 18 (2): 171-173.

Mahadevan A. 1965. Production of protopectinase by Fusarium vasinfectum. Curr. Sci. 19, p. 566.

Marimuthu T., Bhaskaran R., Shanmugam N., Purushothaman D. 1974. In vitro production of cell wall splitting enzymes by Alternaria sesami. Labd. J. Sci. Tech. 12B: 26-28.

Mc Kinney H.H. 1923. A new system of grading plant diseases. J. Agric. Res. 26 (2): 195-218.

Muthulakshmi P. 1990. Studies on fruit rot of chilli (Capsicum annuum L.) caused by Alternaria tenuis Nees. M. Sc. (Ag.) thesis, Tamil Nadu Agric. Univ. Madurai, India, 139 pp.

Nelson S.C. 2006. Species profiles for Pacific island agroforestry, Morinda citrifolia (noni) http://www.traditionaltree.org., p. 18. 
Norkrans B. 1950. Influence of cellulolytic enzymes from hyphomycetes on cellulose preparations of different crystallinity. Physiol. Plantarum 3 (3): 75-85.

Peter P.I. 2009. Energetic vibrations of noni. Noni Search $2009-$ Fourth National Symposium. World Noni Research Foundation, Chennai, India, 25-26 October 2009, p. 18.

Rangaswami G. 1958. An agar blocks technique for isolating soil micro organisms with special reference to Pythiaceous fungi. Sci. Cult. 24, p. 85.

Riker A.J., Riker R.S. 1936. Introduction to Research on Plant Diseases. John Swift Co., St. Louis, Chicago, 117 pp.

Singh R.S. 2002. Introduction to Principles of Plant Pathology. 4th ed. Oxford IBH Publishing Co. Pvt. Ltd, New Delhi, 398 pp.

TNAU (Tamil Nadu Agricultural University). 1980. Score Chart for Crop Diseases. Coimbatore, India, 56 pp.

Wood R.K.S., Balio A., Graniti A. 1972. Phytotoxins in Plant Disease. Academic Press, New York, 530 pp.

Yang Z., Rogers L.M., Song Y., Guo W., Kolattukudy P.E. 2005. Homoserine and asparagines are host signals that trigger in planta expression of a pathogenesis gene in Nectria haematococca. Proc. Natl. Acad. Sci. USA 102: 4197-4202.

\section{POLISH SUMMARY}

WIRULENCJA GRZYBA ALTERNARIA

ALTERNATA PORAŻAJĄCEGO DRZEWO

MORINDA CITRIFOLIA ORAZ WYTWARZANIE

PRZEZ PATOGENA ENZYMÓW DEGRADYJĄCYCH ŚCIANY KOMÓRKOWE

Aby potwierdzić postulaty Kocha testowano różne metody inokulacji. Najlepsze wyniki uzyskano stosując metodę opryskiwania zawiesiną zarodników. Spośród 15 badanych izolatów grzyba Alternaria alternata, izolat AA1 wykazywał wysoki stopień wirulencji, podczas gdy izolat AA6 był awirulentny. Wirulentny izolat grzyba A. alternata wytwarzał w większych ilościach enzymy celulolityczne (C1 i Cx) oraz pektynolityczne (macerujące enzymy, pektyno metyl esterazę i endo-poligalakturonazę) in vitro, w porównaniu do wirulentnego izolatu. Enzymy pektolityczne były bardzo aktywne u 10-dniowych kultur grzyba, a ich aktywność malała wraz z wiekiem izolatu patogena. W przypadku enzymów wytwarzanych przez awirulentny izolat, stwierdzono wzrost ich aktywności wraz z wiekiem kultury grzyba. 